\title{
Archeological Evidences: Embroidered Textiles of the Han and Tang Dynasties (206BC-907AD) Unearthed along the Silk Road
}

\author{
Yanghua Kuang ${ }^{1}$ \\ ${ }^{1}$ School of Fashion \& Art Design, Donghua University, Shanghai, China \\ Correspondence: Yanghua Kuang, School of Fashion \& Art Design, Donghua University, 1882 Yan'an Road \\ West, Shanghai 200051, China. Tel: 86-21-6237-9052. E-mail: tinakyh2005@yahoo.com.cn
}

Received: March 1, 2012

doi:10.5539/ass.v8n8p50

\author{
Accepted: April 2, $2012 \quad$ Published: July 1, 2012 \\ URL: http://dx.doi.org/10.5539/ass.v8n8p50
}

\begin{abstract}
This paper firstly reviews embroidered textiles of the Han and Tang dynasties (206BC-907AD) unearthed along the Silk Road in northwestern China. Then it makes a discussion on the motif, category and technique of embroidered textiles on the basis of archeological evidences. Finally it gives these opinions: the motif shows a comprehensive influence of Central China, local places and the West; the embroidery executed on woolen fabrics found in Xinjiang province shows a local feature; and the transaction from chain stitch to satin stitch may occur during the Northern Dynasties to the early Tang dynasty.
\end{abstract}

Keywords: embroidered textiles, embroidery, the Han and Tang dynasties, the Silk Road

In history, China was in its greatest glory during the Han and Tang dynasties. As textile technique progressed and foreign trade developed, China's silk products were exported to the West through the Silk Road during this period. Two thousand years later, a great number of textiles of the Han and Tang dynasties have been found in the graveyards or ancient sites along the Silk Road. Some textiles, for instance polychrome wove silk and damask, have been intensively studied; some textiles such as embroidered textiles have never been systematically discussed.

\section{Embroidered Textiles of the Han and Tang Dynasties (206BC-907AD) Unearthed along the Silk Road}

Along the Silk Road, embroidered textiles of the Han and Tang dynasties have been unearthed in some graveyards or ancient sites in Xinjiang, Gansu, Qinghai and Shaanxi province. In Xinjiang, they were found in the Shanpula graveyard, the Niya site, the Zagunluk graveyard, the Yingpan site, the Loulan site (the former five date to the Han and Jin dynasties, about 206BC-420AD) and the Astana graveyard (dates to the Northern Dynasties and Tang dynasty, 386-907); in Gansu, Qinghai and Shaanxi, they mainly were found in the Mogao Grottoes in Dunhuang (dates to Tang and Five dynasties, 618-960), the tomb of ancient Tibetan in Dulan (dates to the Tang dynasty, 618-907), the underground repository of Famen Temple in Fufeng (dates to the late Tang dynasty, about 874). In addition, a considerable amount of beautiful embroidered textiles of the Han Dynasty was also found at the kurgans in Noin-Ula, Mongolia. (Although Noin-Ula belongs to Mongolia, it occupied an important position on the northern branch of the Silk Road in Han and Tang dynasties and a great number of silk dating from this period has been unearthed in this place.)

Shanpula: The graveyard of Shanpula is located 14 kilometers to the southwest of Lop County, in Hotan, Xinjiang. Some tombs date to an earlier period, about $1^{\text {st }} \mathrm{BC}-3^{\text {rd }}$ centuries, some tombs date to a relatively later period, about $3^{\text {rd }}-4^{\text {th }}$ centuries. In between 1983-1995, several excavations were made in this graveyard. In 1984, twenty pieces of embroidered textiles or so were unearthed from graveyard I, including pillow fragment, felt bag, boot fragment, face cover, jaw protector, braided ribbon and clothing fragment. Boot fragment, jaw protector and braided ribbon were found in a great quantity. A lot of embroidery is executed on woolen fabrics. Vine and floret are the most popular motifs. In 1992, a fragment embroidered with florets and lozenges, a fragment embroidered with geometrical grasses and lozenges and a fragment embroidered with florets and dots were found at tomb 6 in graveyard II. In 1996, a fragment embroidered with a strange animal (which consists of a bird head and a snake body), a fragment embroidered with deer, a fragment embroidered with florets and lozenges, a fragment embroidered with animals, an arm protector embroidered with deer, a fragment embroidered with geometrical grass, a braided ribbon embroidered with scrolls were unearthed from grave yard 
III.

Niya: The site of Niya is located 150 kilometers to the north of Minfeng County, in Hotan. It dates to Western Han to Eastern Jin dynasties ( $2^{\text {nd }} B C-5^{\text {th }}$ centuries). Embroidered textiles were found in 1959 and 1995. In 1959, a great number of beautiful embroidered textiles were unearthed from a tomb dated back to the Eastern Han dynasty (25-220), including a perfumed powder bag embroidered with clouds, garters embroidered with clouds, a mirror bag embroidered with vines, a pair of man's trousers embroidered with flowers and grasses, a women's underwear embroidered with birds and vines, a piece embroidered with lozenges and flowers etc. In 1995, less embroidered textiles were found. A pair of embroidered leather shoes, a pair of embroidered woolen boots, an embroidered leather bow bag and an embroidered felt blanket were unearthed from tomb 8 in graveyard I. A pair of embroidered leather boots was also unearthed in graveyard I but from tomb 3. And an embroidered hat was also found in this year.

Zagunluk: The graveyard of Zagunluk is located 5 kilometers to the southwest of Qiemo County, in Bayingolin Mongolian Autonomous Prefecture. Some tombs belong to 1000 BC or so, most tombs belong to the Spring and Autumn Period and the Eastern Han dynasty $(770 \mathrm{BC}-220)$ and some tombs date to the Eastern Han and Jin dynasties (25-265). Since 1985, four excavations have been made in this graveyard. In 1985, two embroidered pieces were found, one with a pattern of vortex and triangle (from tomb 3 ) and the other with a pattern of fruits (from tomb 4). In 1996, a fragment from an embroidered boot dated back to 770BC-220 was unearthed from tomb 34, a fragment embroidered with curves dating from 770BC-220 was found from tomb 54 and an fragment embroidered with bird dating from 25-265 was excavated from tomb 49. In 1998, two embroidered pieces dating from 25-265 were unearthed, a ribbon with honeysuckles (from tomb 135) and a fragment with grapes (form tomb 141). Recently, Xinjiang Museum published another nine embroidered woolen fragments (Wang Bo, \& Wang Mingfang, 2010, pp.77-85)

Yingpan: The site of Yingpan is located 150 kilometers to the southeast of Yuli County, in Bayingolin Mongolian Autonomous Prefecture. It dates to the Han and Jin dynasties (206BC-420) or even later. Since 1989, several excavations have been made at this site. In 1989, two woolen pillows embroidered with flowers in lozenges and two pieces from embroidered clothing were unearthed. In 1995, more embroidered textiles were found. Two fan-shaped embroidered pieces and a fragment embroidered with four-petalled florets were found in tomb 19. The host of tomb 15 was in a pair of woolen trousers embroidered with florets in lozenges, with an embroidered arm protector on his left arm and an embroidered cock-shaped pillow under his head. Besides, another embroidered pillow and a pair of embroidered cotton trousers were also found in this tomb. A woolen fragment embroidered with four-petalled florets, a woolen pillow embroidered with dots and vines and a perfume bag embroidered with scrolls were found in tomb 22. In 1999, a fragment embroidered with waves was found in tomb 18 and a piece embroidered with branches and leaves was found in tomb 37.

Loulan: The site of Loulan is located on the bank of Lop Nor to the northeast of Ruoqiang County, in Bayingolin Mongolian Autonomous Prefecture. It dates to the Han and Jin dynasties (206BC-420). Early in the $20^{\text {th }}$ century, Stein found a fragment embroidered with lozenges, a walnut-shaped piece embroidered with vines and a fragment embroidered with flowers here. In 1934, Sven Hedin found a piece embroidered with clouds, a bag embroidered with scrolls and a bag embroidered with dots and scrolls in the area of Lop Nor. In 1980, an embroidered piece with flowers was unearthed from a tomb dating from the early Eastern Han dynasty (about $1^{\text {st }}$ century) in the area northeast to the ancient city of Loulan. In 2003, a pair of mittens embroidered with scrolls, a woolen piece embroidered with scrolls and a triangle-shaped piece also embroidered with scrolls were unearthed from a tomb in the northeast of LE city. Besides, a few embroidered textiles from Loulan are now in private collections.

Astana: The graveyard of Astana is located 40 kilometers to the city of Turfan. It dates to the Northern Dynasties and Tang (386-907). Early in $20^{\text {th }}$ century, Stein found three fragments embroidered with scrolls here. Since 1959, eleven excavations have been made. In 1960 , an embroidered pouch dating from the mid $7^{\text {th }}$ century to mid $8^{\text {th }}$ century was found in tomb 322 and an embroidered pouch dating from the $6^{\text {th }}$ century to the mid $7^{\text {th }}$ century was found in tomb 337; In 1965, a vest (Liangdang in Chinese documents) embroidered with scrolls was unearthed from tomb 39; During 1972-1973, a fragment embroidered with grapes and animals and a garment embroidered with birds and animals, both dating from 304-439, were unearthed from tomb 177 and an embroidered women's underwear dating from the mid $7^{\text {th }}$ century to mid $8^{\text {th }}$ century was found in tomb 152 ; In 1973, an embroidered cotton fragment dating from the $6^{\text {th }}$ century to the mid $7^{\text {th }}$ century and a face cover embroidered with a pattern of linked pearls dating from the mid $7^{\text {th }}$ century to mid $8^{\text {th }}$ century were found respectively in tomb 199 and tomb 237; In 1979, a vest (liangdang) embroidered with birds, dragons and scrolls dating from 304-439 was found in tomb 382 . 
The Mogao Grottoes: In Gansu province, embroidered textiles were mainly found at the Mogao Grottoes in Dunhuang. In 1900, a great number of embroidered textiles were found in Cave 17. They mainly date to the late Tang and Five Dynasties $\left(9^{\text {th }}-10^{\text {th }}\right.$ centuries). The motifs include the image of Buddha or Bodhisattva, lotus, canopy, flower, bird, animal and etc. Most of the textiles from Cave 17 were taken away by archaeological explorers from the West such as Stein, Pelliot and Oldenburg in the early $20^{\text {th }}$ century. They are now collected in Britain, France and Russia etc. In 1965, in the front of Cave 125 and Cave 126 a large embroidered piece was found. It is the earliest example of embroidered textiles found at the Mogao Grottoes, dating from the Northern Wei dynasty (386-534). From top to bottom, it consists of Buddha preaching, an inscription, details of the donors (the king of Guangyang and his families) etc.

Other places in Gansu: Besides Dunhuang, embroidered textiles were also found in other places of Gansu but in small quantities. In 1959, an embroidered needlework box dating from the Eastern Han dynasty (25-220) (from tomb 22), an embroidered decorative border and an embroidered piece depicting garrison on the frontier were unearthed from Mozuizi, in Wuwei. In 1979, an embroidered felt pad and a pair of embroidered felt shoes were excavated from tomb 12 at a beacon site in Maquanwan. In 2002, a pair of trousers embroidered with a two-headed bird dating from about 377 was found in tomb 26 in Bijiatan, Huahai, Yumen.

Dulan: Many textiles of the Tang dynasty were unearthed from the tombs of ancient Tibetan in Dulan, Reshui, Qinghai, but few of them have been published. The embroidered textiles we know found in this place include a beautiful saddleblanket embroidered with big medallions and scrolls and a pair of socks embroidered with small medallions.

Famen Temple: The underground repository of Famen Temple is another important place in which a great number of embroidered textiles of the Tang dynasty have been found. It dates to about 874 and was excavated in the year of 1987. The most wonderful embroidered textiles are a set of miniature costume, consisting of a half-sleeved jacket, a skirt, a kasaya, an apron and a hassock. These items are valuable examples of couched gold embroidery in the Tang dynasty, with gold wrapped threads couched to form patterns. Many embroidered textiles were found in this temple, but most are still in restoring. According to published materials, the motifs include lotus or other large flower, phoenix, butterfly, peacock etc.

Noin-Ula: A great number of beautiful embroidered textiles were unearthed from the kurgans in Noin-Ula, Mongolia. They date to the end of the Western Han dynasty (around the end of $1^{\text {st }}$ century BC to the beginning of $1^{\text {st }}$ century). Some embroidery are executed on wool textiles and some use silk as ground. The representative pieces include a fragment with a two-headed bird and clouds, a felt blanket with animals, a hanging with turtles and fishes, a hanging with birds and fishes, a hanging with tigers' heads, fragments with human and horses, fragments with human's image and fragments with various clouds etc.

\section{Discussion on Related Problems}

\subsection{The Motifs of Embroidery}

In these graveyards or ancient sites, Noin-Ula dates to an earlier period; Shanpula, Niya, Zagunluk, Yingpan and Loulan date to a relatively later period; while Astana, Dulan and Famen Temple date to an even later period. The motifs of embroidery also show the difference of date. Cloud is a common motif and frequently appears on the embroidered textiles from Noin-Ula. It is almost in the same style as that found in Mawangdui (Changsha, Hunan), Haiqu (Rizhao, Shandong) and Yinwan (Donghai, Jiangsu). It shows a feature of embroidery of the Western Han dynasty and an influence from Central China. But some animal motifs on the pieces from Noin-Ula are quite different from those found in Central China. They show a feature of grasslands. The embroidered textiles unearthed from Shanpula, Niya, Zagunluk, Yingpan and Loulan show a decline in cloud motif and the motif of small plants in simple style become popular. Vines and florets are the most popular motifs. Few animal motifs are used. The most common one is bird. Deer and goat on textiles from Shanpula show a local feature. Lozenge is often used as frame and filled with geometrical florets. There are many examples from Shanpula. The motifs of honeysuckle and two-headed bird (from Zagunluk) show an influence from Buddhism which was introduced into China during this period. The pattern of linked pearls, which was very popular in the Tang dynasty, was found on the textiles unearthed from Astana. It shows an influence from Persia. And the motif of grape shows a local feature. Dunhuang is a sacred Buddhist site; therefore many motifs adopted by the embroidered textiles unearthed from the Mogao Grottoes are associated with Buddhism. Besides Buddha or Bodhisattva, objects relating to Buddhism such as lotus and canopy also appear. In addition, the motifs of flowers and birds or other animals are also quite common. However, floral pattern here is quite different from the florets which were previously popular in the Han and Jin dynasty. It is large, gorgeous and in a quite naturalistic style. Geometrical motif has been hardly found in Dunhuang or Fanmen Temple. The medallions on embroidered 
textile unearthed from Dulan show a characteristic of the Tang dynasty. Embroidered textiles from Famen Temple are almost the same in style as those from the Mogao Grottoes but more luxurious.

\subsection{The Categories of Embroidery}

According to ground embroidery can be classified into two groups: embroidery executed on silk textiles and embroidery executed on woolen fabrics. Generally speaking, embroidery unearthed from Central China is executed on silk. As to those I mentioned above, embroidery from the Mogao Grottoes, Famen Temple and Astana (because most of the people in Turfan are Chinese during the Han and Tang dynasties) are executed on silk but embroidery executed on woolen fabrics do exist in Noin-Ula, Shanpula, Niya, Zagunluk, Yingpan and Loulan, especially in Noin-Ula, Shanpula and Zagunluk. The woolen fabrics here include woolen fabric in the structure of tabby, woolen fabric in the structure of twill, braided ribbons and felt. Yet we will perhaps agree that embroidery executed on silk represents the tradition of Central China and embroidery executed on woolen fabrics represents a feature of the local people and also shows an influence from the Central Asian.

\subsection{The Stitches of Embroidery}

Embroidery on the textiles unearthed from Noin-Ula, Shanpula, Niya, Zagunluk, Yingpan, Loulan and Astana are executed in chain stitch while embroidery on the textiles from the Mogao Grottoes and Famen Temple are mainly in satin stitch. However, examples of embroidery executed in satin stitch also found on the textiles from Niya, Loulan and Astana but in quite a few quantities. Therefore, satin stitch should appear much earlier than Tang dynasty, and the archeological evidences show the transition from chain stitch to satin stitch could happen at one time during the Northern Dynasties to the early Tang dynasty. In addition, the stitches also show a development from using a single stitch to combining with other stitches. Embroidery from Xinjiang are rare executed in two stitches, but many embroidery from Cave 17 are executed in several stitches, besides satin stitch, layered stitch, split stitch, couching stitch and long and short stitch etc. are also frequently used.

\section{Conclusion}

Based on the discussion of embroidered textiles unearthed from graveyards or ancient sites along the Silk Road in northwestern China the following conclusions are reached: Firstly, the motif of embroidery shows a comprehensive influence of Central China, local places and the West, and the influence from each factor is different in different places, not only because of location but also because of people; Secondly, embroidery executed on woolen fabrics unearthed from some places in Xinjiang, for instance Shanpula and Zagunluk, shows a local feature, which is also a result of the interaction of Central China and Central Asian; Finally, the transition from chain stitch to satin stitch could happen at one time during the Northern Dynasties to the early Tang dynasty.

\section{References}

Archaeological Team of Loulan. (1988). Loulan chengiiao gumuqun fajue jianbao [Excavation of Ancient Cemetery on the Outskirts of Loulan]. Xinjiang wenwu [Xinjiang Cultural Relics], 7, 23-39.

Archaeological Team of Loulan. (1988). Loulan gu cheng zhi diaocha yu shijue baogao [Investigation and Trial Diggings of the Site of Ancient Loulan]. Wenwu [Cultural Relics], 7, 1-22.

Archaeological Team of Xinjiang Museum. (2000). Astana gumuqun di er ci fajue jianbao [The Second Excavation in Astana Graveyard]. Xinjiang wenwu [Xinjiang Cultural Relics], 3-4, 1-65.

Archaeological Team of Xinjiang Museum. (2000). Astana gumuqun di san ci fajue jianbao [The Third Excavation in Astana Graveyard]. Xinjiang wenwu [Xinjiang Cultural Relics], 3-4, 66-83.

Chen Wanxiong. (Ed.) (1998). Helong wenhua: lianjie gudai Zhongguo yu shijie de zoulang [Culture of Helong: A Corridor Connecting Ancient China and the World]. Shanghai: Shanghai Far East Publishers.

CPAM of Turfan Region: Turfan chutu shi liu guo shiqi de wenshu: Turfan Astana 382 hao mu qingli jianbao [Manuscripts of the Sixteen States Period Unearthed in Turfan: Excavation of the Tomb No.382 at Astana in Turfan]. Wenwu [Cultural Relics], 1, 19-25.

Dunhuang Academy. (1972). Xin faxian de Beiwei cixiu [A New Discovery of Embroidery from the Northern Wei Dynasty (386-534)], Wenwu [Cultural Relics], 2, 54-60.

Li Qing. (2005). Gu Loulan Shanshan yishu zonglun [Ancient Lou-Lan and Shan-Shan Art Summarize]. Beijing: Zhonghua Book Company.

Lubo-Lesnichenko. (1961). Ancient Chinese Silk Textiles and Embroideries, 5th to 3rd Century AD in the State Hermitage Museum (in Russia). Leningrad: State Hermitage. 
S. I. Rudenko. (1969). Die Kultur der Hsiung-nu und die Hugelgraber von Noin Ula. Bonn: R. Habelt.

Sueji Umehara. (1960). Studies of Noin-Ula Finds in North Mongolia. Tokyo: The Toyo Bunko.

Wang Bo, \& Wang Mingfang. (2010). Zagunluk maoxiu [Embroidery Executed on Woolen Fabrics from Zagunluk]. Wenbo [Relics and Museology], 3, 77-85.

Wang Xu. (2001). Condition Report and Preliminary Analysis of Textiles Found in Famen Temple. In Zhao Feng (Ed.), Wang Xu and Textile Archaeology in China. Hong Kong: ISAT/Costume, 120-122.

XinJiang Institute of Archaeology. (1994). Yuli xian Yinban gumu diaocha [Investigation of Ancient Tombs at Yingpan of Yuli County in Xinjiang]. Wenwu [Cultural Relics], 10, 19-31.

XinJiang Institute of Archaeology. (1999). Xinjiang Yuli xian Yingpan mudi 15 hao mu fajue jianbao [Excavation of Tomb 15 at the Yingpan Site, Yuli, Xinjiang]. Wenwu [Cultural Relics], 1, 4-16.

XinJiang Institute of Archaeology. (2000). Astana gumuqun di shi ci fajue jianbao [The Tenth Excavation in Astana Graveyard]. Xinjiang wenwu [Xinjiang Cultural Relics], 3-4, 84-167.

XinJiang Institute of Archaeology. (2000). Astana gumuqun di shi yi ci fajue jianbao [The Eleventh Excavation in Astana Graveyard]. Xinjiang wenwu [Xinjiang Cultural Relics], 3-4, 168-214.

XinJiang Institute of Archaeology. (2000). Lop xian Shanpula II hao mudi fajue jianbao [Excavation in Graveyard II in Shanpula, Lop County]. Xinjiang wenwu [Xinjiang Cultural Relics], 1-2, 11-35.

XinJiang Institute of Archaeology. (2000). Xinjiang Minfeng xian Niya yizhi 95MNI hao mu di M8 fajue jianbao [Excavation of Tomb Coded M8 of Cemetery 95MNI at the Niya Site in Xinjiang]. Wenwu [Cultural Relics], 1, 4-40.

XinJiang Institute of Archaeology. (2002). Xinjiang Yuli xian Yingpan mudi 1995 nian fajue jianbao [Excavation of the Yingpan Site, Yuli, Xinjiang in 1995]. Wenwu [Cultural Relics], 6, 4-45.

Xinjiang Museum. (1960). Xinjiang Minfeng xian bei da shamo gu yizhi muzang qu donghan hezang mu qili jianbao [Excavation of a tomb from Eastern Han in the Desert to the North of Minfeng County, Xinjiang]. Wenwu [Cultural Relics], 6, 9-12.

Xinjiang Museum. (2003). 1998 nian Zagunluk di san qi wenhua muzang fajue jianbao [Excavation in Graveyard Zagunluk in 1998]. Xinjiang wenwu [Xinjiang Cultural Relics], 1, 1-19.

Xinjiang Museum, \& Xinjiang Institute of Archaeology. (2001). Zhongguo Xinjiang Shanpula: gudai Yutian wenming de jieshi yu yanjiu [Sampula in Xinjiang of China: Revelation and Study of Ancient Khotan Civilization]. Urumqi: Xinjiang Peoples Publishing House.

Xinjiang Museum, CPAM of Bayinggolin Mongolian Automonous Prefecture, \& CPAM of Charchan County. (2003). Xinjiang Qiemo Zagunluk yi hao mudi fajue baogao [Excavation of Graveyard No.1 at Zagunluk in Charchan, Xinjiang]. Kaogu xuebao [ACTA Archaeologica Sinica], 1, 89-136, 161-176.

Yamanobe Tomoyuki. (1979). Fabrics from the Silk Road: the Stein Collection, National Museum, New Delhi. Tokyo: Shikosha Publishing Co., Ltd.

Zhao, Feng. (1999). Treasures in Silk. Hong Kong: ISAT/Costume.

Zhao, Feng. (Ed.) (2002). Recent Excavations of Textiles in China. Hong Kong: ISAT/Costume.

Zhao, Feng. (Ed.) (2007). Textiles from Dunhuang in UK Collections. Shanghai: Donghua University Press.

Zhao, Feng. (Ed.) (2008). Western Imprints: Textiles from Han and Jin Dynasties in China. Hong Kong: ISAT/Costume.

Zhao, Feng. (Ed.) (2010). Textiles from Dunhuang in French Collections. Shanghai: Donghua University Press.

Zhao, Feng, \& Yidilisi. (Eds.) (2007). Damo lianzhu: huan takelamagan sichouzhilu fushi wenhua kaocha baogao [An Investigation Report on Costumes Unearthed from Ancient Sites along the Silk Road around Taklimakan Desert]. Shanghai: Donghua University Press. 